\title{
VALIDATION OF LEARNING OUTCOMES GAINED OUTSIDE ACADEMIA: A LITHUANIAN CASE OF PORTFOLIO TRAINING
}

\author{
Nijolė Burkšaitienė \\ Jolita Šliogerienè \\ Institute of Humanities, Mykolas Romeris University, Vilnius, Lithuania
}

\begin{abstract}
The article reports the results of the investigation into adults' views of the portfolio training provided to them by a university before validation of their non-formal and informal learning. This is a mixed-method investigation conducted with the participation of 70 adults with the main aim to establish effectiveness and usefulness of the portfolio training from the adults' perspective. The research results showed that the training was effective and useful. The participants considered that due to the training their $C V$ writing skills improved, the awareness of the process of validation of non-formal and informal learning and of the participation requirements increased, as well as the ability to develop one's portfolio of non-formal and informal learning was developed.

The results of the participants' feedback responses revealed five major categories of usefulness, including relevant information, abilities developed during the training, new knowledge gained during the training, the use of metacognitive strategies, and practical value of the training.

The research contributes to the literature in that it increases our understanding of what adults view as relevant with regard to institution-provided support before the validation procedure of their non-formal and informal learning, which may lead to a better mutual understanding and result in adult success.
\end{abstract}

Keywords: effectiveness and usefulness of portfolio training; higher education; participants' perspective; validation of non-formal and informal learning.

\section{Introduction}

Validation of non-formal and informal learning has been on the European lifelong learning policy agenda since 20011. Since then higher education (HE) systems of the European Higher Education Area (EHEA) have been under the process of change. To enhance the process, in 2008, the European University Association (EUA) on the request of the French authorities and after extensive

\footnotetext{
${ }^{1}$ In the present study the term Validation is used to describe a process of confirmation by an authorised body that an individual has acquired learning outcomes measured against a relevant standard (Proposal for a Council recommendation on the validation of non-formal and informal learning, 2012, Brussels: European Commission, 5.9.2012, COM(2012) 485 final 2012/0234 (NLE), p. 17).
} 
Nijolè Burkšaitienè, Jolita Šliogerienè. Validation of Learning Outcomes Gained Outside Academia: a Lithuanian Case of Portfolio Training

consultations with the EUA member universities, rectors' conferences and education stakeholder institutions adopted European Universities' Charter on Lifelong Learning (2008). It sets 10 commitments from governments and 10 commitments from universities to implement the idea of lifelong learning. Among the latter, two commitments are of utmost importance, i.e. universities should adapt study programmes to ensure that they are designed to widen participation and attract returning adult learners as well as to develop systems for the validation of all forms of prior learning (European Universities' Charter on Lifelong Learning, 2008, p.5, 6).

In 2011, the Council concluded that HE requires modernisation, has to become more open by creating flexible learning paths and being able to provide clear routes of entering $\mathrm{HE}$ from other sectors of education (Council recommendation ..., 2011). To this end, the EHEA members were called to reform their national education systems so that to establish systems for the validation of non-formal and informal learning and design plans of their implementation at all levels of education, including HE.

The overview of the literature and documents shows that at present the situation across 47 EHEA members differs considerably. The existing differences include the level of strategy formation and legal regulation, purposes of validation, participation of stakeholders, sources of financing, and the terminology used to define the process (Bjørnåvold, 2009; Duvekot, 2009; Burkšaitienė \& Šliogerienė, 2010; The European higher education area ..., 2012; The European higher education area ..., 2015). To illustrate, according to Bologna Process Implementation Report 2015, in more than half of the EHEA members (28) it is still not possible for adults to be admitted to HE on the basis of recognition of non-formal and informal learning (The European higher education area ..., 2015). Another example is that even though in nine systems at least some types of HE institutions (e.g. universities of applied sciences) or programmes are already open to admission based on recognition of non-formal and informal learning, admitting adults without standard qualifications is a legal right in only eight systems (Belgium (French Community), Denmark, France, Germany, Luxembourg, Norway, Portugal and Sweden).

The existing differences regarding the possibility to have non-formal and informal learning recognised towards the fulfilment of a study programme are significant, too. For example, it is reported that in 29 systems adults have such a legal right, however, in most cases (20), it can only lead to a limited number of credits. Besides, even though in nine systems (Belgium (Flemish Community), Denmark, Finland, France, Ireland, Luxembourg, Malta, the Netherlands and the United Kingdom (except Scotland)) recognition of non-formal and informal learning can lead to a complete award of a HE qualification, it is only France who has a well-established and commonly used practice to do this. In the rest eight 
systems, it is more a theoretical possibility or still in the progress of being developed rather than a common practice (The European higher education area ..., 2015). Finally, it is established that in 17 EHEA members, recognition of prior non-formal and informal learning is not used at all, neither for admission to nor for progression in HE (The European higher education area ..., 2015).

In Lithuania, validation of non-formal and informal learning has been on the education policy agenda since 1998 (Republic of Lithuania Law on Adults' Nonformal Education, 1998). Legal regulation for the validation of non-formal and informal learning in HE was laid down in The Law on Higher Education and Research (Republic of Lithuania Law on Higher Education ..., 2009). According to the law, adults can be admitted to an institution of $\mathrm{HE}$ on the basis of the assessment procedure laid down in institutional legal acts. In 2010, Recommendations on the assessment and recognition of competences gained through the system of non-formal education in HE institutions were adopted by the Order of the Minister of Education and Science (Neformaliojo suaugusiuju švietimo sistemoje igytu kompetencijų vertinimo ir pripažinimo aukštosiose mokyklose rekomendacijos ..., 2010). They provide for the principles of assessment and recognition of non-formal and informal learning, define the learning environments from which adults' learning outcomes can be validated in Lithuanian HE institutions, and establish the limit of $75 \%$ of credits that can be awarded for their learning outcomes gained outside academia. At present, a network of HE institutions implementing validation of non-formal and informal learning has been created in Lithuania, and adults can use their right to take a nontraditional route of access to $\mathrm{HE}$.

\section{The theoretical perspective}

The research literature proves that adults' success in the process of validation of non-formal and informal learning in HE is determined by several factors. They include the choice of an appropriate assessment paradigm, creation of reliable assessment methodologies, training assessors, as well as institutional support provided to adults (Peters et al., 2004; Peters, 2005; Costley \& Armsby, 2007; Chisholm \& Davies, 2007; Burkšaitienė \& Šliogerienè, 2010, Burkšaitienè, 2015).

It has been established by research that the role of institutional support is crucial. To illustrate, the findings of Peters et al. (2004) show that adults should be supported in coping with the challenge to link their experience to specific learning outcomes and match them in line with those set out in a study programme. Burkšaitienè et al. (2011) concluded that portfolio training provided to adults by an HE institution supported them in documenting personal and professional growth as part of their learning outcomes gained outside academia. 
Nijolè Burkšaitienè, Jolita Šliogerienè. Validation of Learning Outcomes Gained Outside Academia: a Lithuanian Case of Portfolio Training

Sandberg \& Andersson (2011) and Pokorny (2013) underlined that in order to support fairness of the process of assessment and recognition in HE, a mutual understanding between the assessor and the assessee is relevant, whereas Burkšaitiene (2015) suggested that institutional support to adults can be fostered by strengthening consultants' training and closing the gaps in their performance.

The aim of the present research is to analyse institution-provided support (a portfolio training) from the adults' perspective in order to establish its effectiveness and usefulness. To gain a better understanding of adults' views regarding the portfolio training, their responses to feedback questionnaires were investigated.

\section{The method}

The present research is a mixed-method investigation aimed to establish the adults' views regarding effectiveness and usefulness of a portfolio training. In the research, quantitative and qualitative research methods were used.

The participants. The research was conducted with the participation of 70 volunteer adults (58 females, $83 \%$ and 12 males, $17 \%$ ). The participants' age ranged from 20 to 58. According to their education, the adults fell into 5 groups: 38 of them (54\%) had higher university education, 14 of them (20\%) had higher non-university education, 5 participants $(7 \%)$ finished vocational schools, 6 (9 $\%)$ had secondary education, and $6(9 \%)$ stated they did not complete higher education (were drop-out students); 1 adult (1\%) did not present information regarding his/her education.

The procedure. All the participants met the minimum requirements of education and work experience for the assessment procedure, claimed to have participated in lifelong learning processes and have gained learning outcomes through different non-academic learning environments.

The portfolio training consisted of six workshops (12 academic hours) followed by on-line consultations (20 academic hours). The training aimed to (1) provide the participants with information and knowledge regarding the concepts, procedures and principles of validation of non-formal and informal learning in HE, (2) develop their ability to reflect on learning, identify learning outcomes acquired through diverse learning environments and establish a link between them and the expected learning outcomes of a particular study programme, and (3) develop the ability to support their claim for credit with relevant evidence as well as present it in one's portfolio of non-formal and informal learning outcomes.

To support the adults, all of them received a copy of a manual on how to develop a structured portfolio of one's learning outcomes gained outside academia. During the workshops, the adults were guided on how to write a CV 
(according to the EU format), reflect and self-assess one's non-formal and informal learning, as well as support it with relevant evidence.

To gain a deeper understanding of the adults' views regarding effectiveness and usefulness of the portfolio training, their feedback responses were analysed. The feedback questionnaire consisted of two parts. Section I studied demographic data and Section II measured effectiveness and usefulness of the portfolio training. The latter section included both close-ended and open-ended questions. To investigate the data, quantitative research methods (descriptive statistics, ANOVA, Pearson correlation statistics, post-hoc test) and the qualitative research method of content analysis were used. To analyse close-ended questions, the Likert-type scale of measurement with a three-point scale of agreement ranging from 'I agree' to 'I disagree' was applied.

Effectiveness of the training was analysed from the perspectives of developed skills, acquired new knowledge and information about the possibilities of validation of non-formal and informal learning outcomes. To establish the adults' views of usefulness of the training, content analysis of their responses to the open-ended question "What was the most useful in the portfolio training?" as well as additional comments were analysed.

\section{The research results}

Effectiveness of the training. Regarding the workshops that were carried out to pilot a portfolio method, the majority of the research participants considered the process to be very well organised and informative. Based on their feedback, $95 \%$ of them $(n=67)$ improved their skills of developing a portfolio of nonformal and informal learning and fostered their CV writing skills. About $98 \%$ $(n=69)$ indicated that their awareness regarding the assessment procedure increased and that they gained a better understanding of recognition possibilities available to them and the requirements for assessment, with further $90 \%(\mathrm{n}=63)$ stating that due to the training, they were able to develop a portfolio and present their non-formal and informal learning outcomes for the procedure of assessment and recognition.

According to university lecturers who provided advisory assistance to the training participants by email, the majority of the adults provided detailed descriptions of their learning outcomes in their portfolios and around half of them could present a claim for university credits for their knowledge and skills gained outside academia after the training.

The research also revealed that there was a need for the validation of nonformal and informal learning outcomes at the university. It was established that the majority of the respondents, including 26 mature adults (33\%) and 16 adults $(22 \%)$ of middle age (up to 39 years of age), had gained non-formal and informal 
Nijole Burkšaitienè, Jolita Šliogerienè. Validation of Learning Outcomes Gained Outside Academia: a Lithuanian Case of Portfolio Training

learning outcomes and were willing to participate in the procedure of validation at the university. It is worth noting that 43 adults $(61 \%)$ had more than 15 years of work experience in the field in which they did not have a higher education qualification (Table 1).

Table 1 The respondents' distribution according to their work experience

\begin{tabular}{|c|c|c|c|c|}
\hline Work experience & Frequency & Percent & Valid percent & $\begin{array}{l}\text { Cummulative } \\
\text { percent }\end{array}$ \\
\hline No work experience & 2 & 2,9 & 2,9 & 2,9 \\
\hline Less than 5 years & 5 & 7,1 & 7,1 & 10,0 \\
\hline 6-10 years & 10 & 14,3 & 14,3 & 24,3 \\
\hline 11-15 years & 10 & 14,5 & 14,5 & 38,6 \\
\hline$>$ 15 years & 43 & 61,4 & 61,4 & 100,0 \\
\hline Total: & 70 & 100,0 & 100,0 & \\
\hline
\end{tabular}

The results of the research also showed that the study fields in which the respondents had the biggest number of non-formal and informal learning outcomes included management, foreign languages, psychology, and social work (Figure 1).

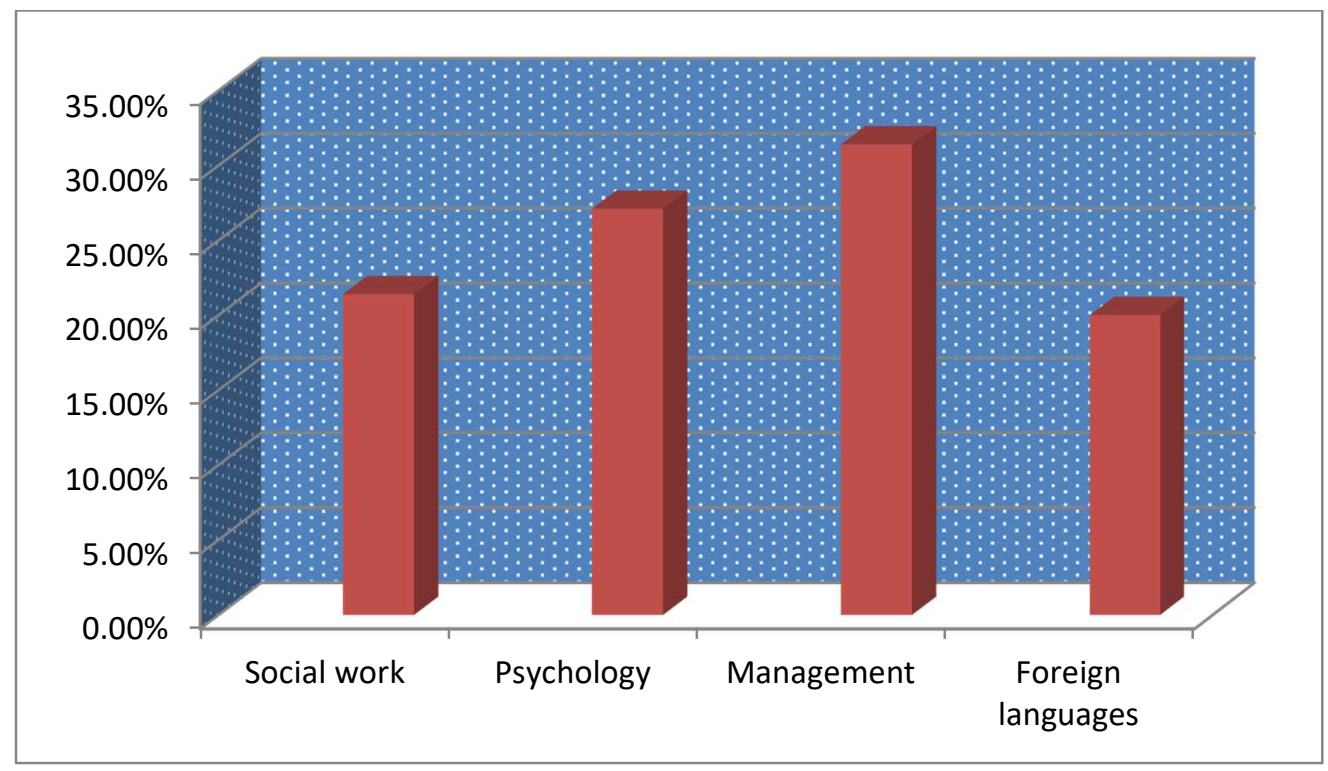

Figure 1 The participants' distribution according to the study fields

ANOVA revealed that there was a statistically significant difference between the study fields and the learning environment called 'independent learning' $F$ (5, $1247)=2.841, p<0.001$. A significant correlation established between these variables leads to the assumption that through independent learning (informal learning including) the respondents gained learning outcomes that could be documented as well as assessed and recognised at the university. The research 
results also showed a difference between the age groups and the study field in which the respondents had gained learning outcomes (Table 2).

Table 2 The distribution between the respondents' age and study field

\begin{tabular}{|c|c|c|c|c|c|c|c|c|c|c|}
\hline \multicolumn{11}{|c|}{ The study field and age } \\
\hline & & & \multicolumn{7}{|c|}{ Your age } & \multirow[t]{2}{*}{ Total } \\
\hline & & & $\mathbf{n} / \mathbf{a}$ & $20-25$ & $26-30$ & $31-35$ & $36-40$ & $>40$ & $\begin{array}{c}\text { up to } \\
20\end{array}$ & \\
\hline \multirow{8}{*}{ 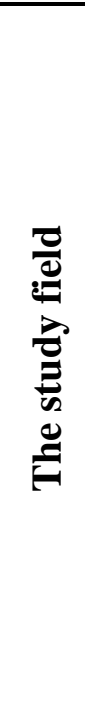 } & \multirow{2}{*}{$\begin{array}{l}\text { Foreign } \\
\text { language }\end{array}$} & $\mathbf{N}$ & 4 & 0 & 1 & 2 & 0 & 7 & 0 & 14 \\
\hline & & $\%$ & $\begin{array}{c}28,6 \\
\%\end{array}$ &, $0 \%$ & $7,1 \%$ & $14,3 \%$ &, $0 \%$ & $\begin{array}{c}50,0 \\
\%\end{array}$ &, $0 \%$ & $100,0 \%$ \\
\hline & \multirow{2}{*}{$\begin{array}{c}\text { Manage- } \\
\text { ment }\end{array}$} & $\mathbf{N}$ & 8 & 1 & 0 & 3 & 3 & 7 & 0 & 22 \\
\hline & & $\%$ & $\begin{array}{c}36,4 \\
\%\end{array}$ & $4,5 \%$ &, $0 \%$ & $13,6 \%$ & $13,6 \%$ & $\begin{array}{c}31,8 \\
\%\end{array}$ &, $0 \%$ & $100,0 \%$ \\
\hline & \multirow[b]{2}{*}{ Psychology } & $\mathbf{N}$ & 1 & 3 & 2 & 3 & 4 & 3 & 3 & 19 \\
\hline & & $\%$ & $\begin{array}{c}5,3 \\
\%\end{array}$ & $15,8 \%$ & $10,5 \%$ & $15,8 \%$ & $21,1 \%$ & $\begin{array}{c}15,8 \\
\%\end{array}$ & $\begin{array}{c}15,8 \\
\%\end{array}$ & $100,0 \%$ \\
\hline & \multirow[b]{2}{*}{$\begin{array}{c}\text { Social } \\
\text { work }\end{array}$} & $\mathbf{N}$ & 2 & 1 & 1 & 0 & 1 & 9 & 1 & 15 \\
\hline & & $\%$ & $\begin{array}{c}13,3 \\
\%\end{array}$ & $6,7 \%$ & $6,7 \%$ &, $0 \%$ & $6,7 \%$ & $\begin{array}{c}60,0 \\
\%\end{array}$ & $6,7 \%$ & $100,0 \%$ \\
\hline \multirow{2}{*}{\multicolumn{2}{|c|}{ Total }} & $\mathbf{N}$ & 15 & 5 & 4 & 8 & 8 & 26 & 4 & 70 \\
\hline & & $\%$ & $\begin{array}{c}21,4 \\
\%\end{array}$ & $7,1 \%$ & $5,7 \%$ & $11,4 \%$ & $11,4 \%$ & $\begin{array}{c}37,1 \\
\%\end{array}$ & $5,7 \%$ & $100,0 \%$ \\
\hline
\end{tabular}

The application of the Bonferroni criterion in a post hoc test tabulated a statistically significant difference $(F(5,1247)=12.631, p<0.001)$ between the age group and the study field of non-formal and informal learning outcomes. It was established that the study fields in which the respondents had non-formal and informal learning outcomes according to the age group differed between the variables 'management' and 'foreign languages' as well as 'psychology' and 'foreign languages', the $p$ value being < 0.001 . Thus, the research results proved that there was a need for the validation of non-formal and informal learning outcomes gained in four fields, mainly in management, social work, psychology, and foreign languages.

Usefulness of the training. The research results revealed that $99 \%$ of the participants $(n=69)$ responded to the question "What was the most useful in the portfolio training?" and that some of them provided more than one answer. Content analysis of all responses revealed five categories of adult-viewed 
Nijolè Burkšaitienè, Jolita Šliogerienè. Validation of Learning Outcomes Gained Outside Academia: a Lithuanian Case of Portfolio Training

usefulness, which included relevant information, abilities fostered during the training, relevant knowledge gained during the training, the use of metacognitive strategies, and practical value of the training. The categories were further analysed, which resulted in the identification of sub-categories, and samples provided.

Category 1. Relevant information. It was established that 21 adults (29\%) considered that the information, which they received during the portfolio training, was the most useful. Deeper analysis revealed two sub-categories:

Sub-category 1 . The information regarding the possibility to have nonformal and informal learning outcomes validated at the university and /or the information regarding the process of validation of such learning (reported by 16 adults). Here are some sample responses: "The information about validation of non-formal learning outcomes was the most useful", "The information about the process of assessing informal learning outcomes was the most useful", "To learn about the possibility to have my learning outcomes assessed and how to do that was the most useful" or "<The information > How to earn credits on the basis of work-based learning ...", "How to formalise non-formal learning outcomes, which I think may be valuable in the future", and "The information about the requirements for portfolio development".

Sub-category 2. The information about the existing types of learning (reported by 5 adults), which can best illustrated by the following responses: "I learnt about non-formal learning for the first time in my life", "I learnt what nonformal learning is, to develop one's portfolio and write a CV, "Now I know about the existing types of learning", and "The information about the types of learning ... As the result, and I got to know myself better and identified the types of learning that I have experienced".

Category 2. Abilities developed during the portfolio training. The findings showed that 21 adults $(29 \%)$ stated that the portfolio training developed their abilities, which they viewed as the most useful. Deeper analysis revealed the following sub-categories:

Sub-category 1. The ability to reflect and self-assess one's own learning and / or present it in the portfolio (reported by 9 adults), e.g. "I've been interested in non-formal learning for a long time. Learning how to reflect on my own learning was especially useful" and that it was useful "to present my knowledge and abilities in a portfolio, to write my CV, and to reflect".

An important finding of the research was that one adult identified these abilities as being useful not only for the present, but also for the future: “... to self-assess my non-formal and informal learning and to write a reflection-based analysis. This opened new horizons and will be useful in the future". Another important finding was that one adult considered that these abilities were the most useful as they made an impact on his/her insights regarding himself/herself: "Self- 
analysis of my own learning and presenting it in a portfolio, which led to a deeper understanding of my own abilities and knowledge that I have".

Sub-category 2. The ability to write one's CV (reported by 3 adults), e.g. "<The most useful was > to learn to write my EU CV", "To write my extended $C V$. It helped me to disclose myself and better present my knowledge and abilities" or "My CV writing skills improved".

Sub-category 3. The ability to develop one's portfolio of non-formal and informal learning (reported by 3 adults), e.g. "<The most useful was $>$ to develop my portfolio as it's the basis for validation of knowledge and skills in order to gain credits", “... to develop my portfolio. I think it makes a difference as it allows to self-assess myself. It can be used for employment and in gaining credits", and "<The most useful was > ... to write my portfolio".

Sub-category 4. A combination of abilities, including writing a CV and developing one's portfolio (reported by 2 adults). To illustrate, they stated that the most useful was "<To learn> what non-formal learning is, to develop my portfolio and write a CV" or "... to write my CV and draft my portfolio".

Sub-category 5. A combination of abilities, including the ability to write a $\mathrm{CV}$, develop one's portfolio, reflect on learning and self-assess it (reported by 3 adults). The adults noted that the most useful was "To write my extended $C V$, reflection pages on my learning and compile my portfolio" and "Portfolio development, writing my $C V$, reflecting and self-assessing my learning" or "Present my knowledge and abilities in a portfolio, to write my $C V$, and to reflect".

Sub-category 6 . The ability to document learning (reported by 1 adult), e.g. "<The most useful was the ability > to document my learning by providing proof".

Category 3. Knowledge gained during the training. The findings showed that seven participants $(10 \%)$ viewed that knowledge which they gained during the portfolio training was the most useful. Deeper analysis revealed two subcategories:

Sub-category 1. Knowledge of how to write a CV and / or develop one's portfolio and / or reflect on learning (reported by 6 adults). Two of them considered that the most useful was knowledge of how to write a CV: "The most useful was to gain knowledge of how to write my CV according to the EU format".

Two other adults reported that both knowledge of how to write a CV and how to reflect on learning was the most useful: "The most useful was to get to know how to write my CV and reflection pages". One adult stated that the most useful was "To learn how to put everything into a portfolio as it is the main document proving that I have knowledge and skills necessary to get credit award".

It is worth mentioning that one adult reported that new knowledge resulted in his/her personal growth: "The biggest value was to get to know how to write an 
Nijolè Burkšaitienè, Jolita Šliogerienè. Validation of Learning Outcomes Gained Outside Academia: a Lithuanian Case of Portfolio Training

extended $C V$ and develop my portfolio of learning. As the result, I analysed my experience and got to know myself better".

Sub-category 2. It was established that one adult viewed knowledge about the assessment procedure as the most useful: "For me, the most useful was knowledge regarding the assessment procedure of non-formal and informal learning at the university".

Category 4. The use of metacognitive strategies. Contents analysis revealed that four adults $(6 \%)$ considered that using metacognitive strategies during the training was the most useful. Three of them reported that it was the metacognitive strategy of analysis, e.g. "... As the result, I analysed my experience and got to know myself better", "During the training I learnt how to systemically approach my experience...", and "The training made me think and analyse things that had seemed irrelevant information". On the other hand, one adult stated that it was the use of the metacognitive strategy of decision-making that was the most valuable: "As the result of the course I made up my mind about further learning...".

Category 5. Practical value of the course. It was established that eight respondents $(11 \%)$ viewed practical aspects of the portfolio training as the most useful. Five of them reported that the manual, the handouts and the slides had the biggest value. They said that "Learning materials were perfect; they'll be very useful for the development of my portfolio", "Learning materials were very well prepared", as well as that "Slides were the most useful as they contained detailed information ...".

Three other adults stated that recommendations and samples of analysis of non-formal and informal learning and reflection pages presented to them during the portfolio training were of the biggest value: "Lecturers' recommendations of how to analyse my learning outcomes", "Practical recommendations and samples of analysis and reflections were particularly useful”, "...Recommended literature was very useful".

Finally, content analysis of the participants' additional comments on the portfolio training showed that it was successful and had added value. This can be supported by the following responses: "I am happy to have had a possibility to gain this competence, and I'll be able to use it in my job in the future", "The project idea was very interesting and I think it will help many people in the future" or "This is a perfect project to seek higher education; it saves time and financial resources. It perfectly suits older people, highly qualified practitioners who, due to different reasons, could not earn a higher education qualification before". 


\section{Conclusions}

The present research provides a source of information on the adults' views of the portfolio training provided by to them by a university aimed to support them before the assessment of their non-formal and informal learning. The results of the research have increased our awareness of how the adults' perceived this type of training with regard to its effectiveness and usefulness.

The findings of the investigation into effectiveness of the portfolio training provided to the research participants by the university revealed that they viewed it as effective and informative. It was established that they considered that as the result of the portfolio training their skills of writing expanded CVs improved and their awareness of the possibilities available for them to validate non-formal and informal learning outcomes increased. Besides, they gained a better understanding of the requirements for the participation in the procedure of validation at the university as well as of the ways to document their non-formal and informal learning outcomes in a portfolio. The research participants also stated they learnt how to identify and describe the study fields in which they had the biggest number of non-formal and informal learning outcomes.

The research results allow to conclude that the university-provided portfolio training was viewed as very useful or useful. The investigation resulted in the identification and description of five categories of usefulness, which includes relevant information, abilities fostered during the training, relevant knowledge gained during the training, the use of metacognitive strategies, and practical value of the training. This is in line with the findings of Peters et al. (2004) who stressed the importance of the portfolio courses in raising adults' awareness of what portfolio development entails and add to the findings of Burkšaitienè et al. (2011) who concluded that portfolio training can become a form of support which empowers adults to disclose their learning that occurred outside academia.

Finally, the findings reinforce the research which emphasises the role of institution-provided support to adults (Rydel, 2004; Peters et al., 2004; Burkšaitienè et al., 2011; Pokorny, 2013) by arguing that through understanding what adults find useful, HE institutions can best adapt their support mechanisms in order to provide the support that adults need the most.

The study contributes to the literature in that it increases our understanding of what adults view as relevant with regard to institution-provided support, which may lead to a better mutual understanding and result in adult success.

\section{References}

Bjørnåvold, J. (2009). Validation of Non-formal and Informal Learning in Europe: Key Developments and Challenges. Aukštojo Mokslo Kokybe / The Quality of Higher Education, 6, 36-71. 
Nijolè Burkšaitienè, Jolita Šliogerienè. Validation of Learning Outcomes Gained Outside Academia: a Lithuanian Case of Portfolio Training

Burkšaitienè, N. (2015). Assessment and Recognition of Non-formal and Informal Learning: a Lithuanian Case of Novice Consultants' Experience. (2015). International Journal of Lifelong Education, 34 (6), 643-662.

Burkšaitienè, N., \& Šliogerienė, J. (2010). Neformaliojo ir savaiminio mokymosi pasiekimu vertinimas ir pripažinimas universitete / Assessment and Recognition of Non-formal and Informal Learning at the University. Vilnius: Mykolas Romeris University.

Burkšaitienè, N., Teresevičienè, M., \& Kaminskienė, L. (2011). Portfolio Use for Documentation of Personal and Professional Growth Gained Outside Academia. Baltic Journal of Management, 6 (2), 245-262.

Chisholm, C., \& Davis, M. (2007). Analysis and Evaluation of Factors Relating to Accrediting $100 \%$ of Prior Experiential Learning in UK Work-based Awards. Assessment \& Evaluation in Higher Education, 32 (1), 45-59.

Costly, C., \& Armsby, P. (2007). Work-based Learning Assessed as a Field or Mode of Study. Assessment and Evaluation in Higher Education, 32 (1), 21-33.

Council Recommendation of 20 December 2012 on the Validation of Non-formal and Informal Learning (2012/C 398/01). Official Journal of the European Union. Downloaded from http://eur-lex.europa.eu/legal-content/EN/TXT/PDF/?uri=CELEX:32012H1222(01)\& from $=\mathrm{EN}$

Duvekot, R. (2009). The Many Perspectives of Valuing Learning. Aukštojo Mokslo Kokybe / The Quality of Higher Education, 6, 72-93.

European Universities' Charter on Lifelong Learning. (2008). Brussels: European University Association. Downloaded from http://www.eua.be/Libraries/higher-education/ eua_charter_eng_ly-(5).pdf?sfvrsn=0

The European Higher Education Area in 2012: Bologna Process Implementation Report. (2012). Brussels: Education, Audiovisual and Culture Executive Agency.

The European Higher Education Area in 2015: Bologna Process Implementation Report. (2015). Luxembourg: Publications Office of the European Union. Neformaliojo suaugusiuju švietimo sistemoje igytu kompetencijų vertinimo ir pripažinimo aukštosiose mokyklose rekomendacijos: Lietuvos Respublikos švietimo ir mokslo ministro $2010 \mathrm{~m}$. gruodžio $15 \mathrm{~d}$. isakymas Nr. V-2319 / Recommendations on the Assessment and Recognition of Competences Gained through the System of Non-formal Education in Higher Education Institutions. (2010). Valstybès Žinios, 152-7763.

Proposal for a Council Recommendation on the Validation of Non-formal and Informal Learning. (2012). Brussels: European Commission, 5.9.2012, COM (2012) 485 final 2012/0234 (NLE).

Peters, H. (2005). Contesting Discourses: Assessing the Outcomes of Learning from Experience for the Award of Credit in Higher Education. Assessment and Evaluation in Higher Education, 30, (3), 273-85.

Peters, H., Pokorny, H., \& Johnson, L. (2004). Cracking the Code: The Assessment of Prior Experiential Learning at London Metropolitan University. In: Michelson, E., Mandell, A. (Eds). Portfolio Development and the Assessment of Prior Learning: Perspectives, Models, and Practices (pp. 160-179). Stylus: Sterling.

Pokorny, H. (2013). Portfolios and Meaning Making in the Assessment of Prior Learning. International Journal of Lifelong Education, 32 (4), 518-534.

Proposal for a Council Recommendation on the Validation of Non-formal and Informal Learning. (2012). Brussels: European Commission, 5.9.2012, COM(2012) 485 final 
2012/0234 (NLE). Downloaded from http://ec.europa.eu/transparency/regdoc/rep/1/ 2012/EN/1-2012-485-EN-F1-1.Pdf

Republic of Lithuania Law on Adults' Non-formal Education (No VIII-822), 30 June 1998. Downloaded from https://www.e-tar.lt/portal/lt/legalAct/TAR.CE3B174CA7E6

Republic of Lithuania Law on Higher Education and Research (No XI-242), 30 April 2009. Downloaded from http://planipolis.iiep.unesco.org/upload/Lithuania/Lithuania_Law_ on_HE_and_Research_2009.pdf

Rydel, S. T. (2004). Building on the Past, Moving toward the Future: Prior Learning Assessment in a Changing Institution at Metropolitan State University. In: Michelson, E., Mandell, A. (Eds). Portfolio Development and the Assessment of Prior Learning: Perspectives, Models, and Practices (pp. 180-193). Stylus: Sterling.

Sandberg, F., \& Andersson, P. (2011). RPL for Accreditation in Higher Education: As a Process of Mutual Understanding or Merely Lifeworld Colonisation? Assessment \& Evaluation in Higher Education, 36 (7), 767-780. 